\title{
The Analysis of Swearing Word Translation in Joker Movie Subtitle
}

\author{
Hapni Nurliana H. D. Hasibuan \\ Applied Linguistics Study Program \\ Universitas Negeri Yogyakarta \\ Indonesia \\ hapninurliana.2019@student.uny.ac.id
}

\section{Tadkiroatun Musfiroh}

Applied Linguistics Study Program

Universitas Negeri Yogyakarta

Indonesia

Citation: Hasibuan, H.N.H.D \& Musfiroh, T. (2021). The analysis of swearing word translation in Joker Movie subtitle. Notion: Journal of Linguistics, Literature, and Culture Vol 3(2), p. 65-74. http://doi.org/notion.v3i2.4852

Article Info

Article History

- Article Received September 14 $4^{\text {th }}, 2021$

- Article Accepted October $20^{\text {th }}, 2021$

\section{Keywords:}

translation swearing word types of swearing translation procedure
ABSTRACT

This research discusses the analysis of swearing words translation in the Joker movie. The purpose of this research is to describe the type of swearing word and the procedure used in translating swearing word. This study uses qualitative methods. The research data were obtained from English subtitles to Indonesian Joker movies. To answer the research question, the researcher used the theory types of swearing word proposed by Swan[15] and procedure translation proposed by Newmark[12] The results revealed that there were 49 swearing words. There are 2 types of swearing words namely: strong and weak swearing words. For strong swear words classified to exclamation of annoyance, surprise, insult, surprise question and emphasize the emotion and the weak swear word classified to exclamation of annoyance, surprise, insult and emotion. After that, procedures translation used in translating swear words only found 5 of 15 procedure translation in Joker's subtitle, namely: cultural equivalent, synonymy, throughtranslation, shift or transposition, and paraphrase. The most frequently type of swearing word is emphasize an emotion from strong swear word. Furthermore, the cultural equivalent procedure is the most used in translating. 


\section{Hasibuan, H.N.H.D. \& Musfiroh, T. The Analysis of Swearing Word Translation in Joker Movie Subtitle}

\section{INTRODUCTION}

Watching movies is becoming a more popular activity supported by technological and multimedia developments on television or the cinema. There are many types of movies that are produced every month in the movie industry around the world, for example, action movies, adventure, documentaries, science fiction, fantasy, thriller, and so on. The results of a study conducted by Bernschutz show that the most popular program recommended for translation is cinema movie. This is also evident from the high demands of television or movie theaters who are constantly looking for good translators to translate their subtitles.

On the other hand, the use of swearing words in movies from time to time is increasing. Researchers assume that it is due to cultural changes that cannot be avoided. Freedom to express feelings is one of the changes in culture that has emerged recently. This has caused the use of swearing words to increase, especially in western culture. Nowadays, many movies often use swearing words in their dialogue to emphasize that the conversation is more interesting, for example: "She is so damn beautiful". The use of the word "damn" is to emphasize a very beautiful woman. This is in line with Janet Holmes's statement in the book An Introduction to Sociolinguistics (2013), swearing words present many different functions in different social contexts. In general swearing words are very rude, abusive, or offensive and are also related to insults to others, or related to strong feelings toward something. Humans may express resentment, aggression and humiliation, or they can express solidarity and friendliness.

Research conducted by Vitasari[16] and Dewi[3] shows that the use of swearing words is now more often used in films. They also mentioned that there were many problems in defining the meaning of swearing words in the target language. Because many problems stem from swearing word translations, researchers also use previous research aimed at contributing to efforts to find out the types of translation procedures as a reference for writing research. Previous research that the researchers mentioned previously serves as a benchmark for researchers in finding swearing word translations from English to Indonesian and finding out the types of translation procedures used by translators in translating swearing words from English into Indonesian.

There were many problems in defining the meaning of swearing words in the target language. It was one of the challenges that faced by the translators. The translators have to use the right procedure while translating swearing word. It can be one or more procedures to make the watcher understand the movie. Therefore, the researcher wants to find the procedure that used in one of famous movie. The source of research is the English and Indonesian subtitles from the 2019 joker movie.

\section{Translation Procedures}

In translation there are types of procedures proposed by Newmark[12]. The following procedures proposed by Newmark are transference, naturalization, cultural equivalent, functional equivalent, descriptive equivalent, componential analysis, synonymy, through-translation, shifts or transpositions, modulation, recognized translation, compensation, paraphrase, couplets, and notes.

\section{a. Transference.}

Newmark revealed that transference is the process of transferring SL words (source language) to TL (target language) text and that includes transliteration. That is the same as what Harvey [5] calls transcription. In other words, transference is the transfer of words or expressions from SL directly to TL without translating them at all. For example:

(SL) White House: istana kepresidenan (TL)

(SL) Kursyyiun (Arabic): kursi (TL)

\section{b. Naturalization.}

Naturalization is a translation process that transfers and adjusts the words of the first source language to normal pronunciation, then is naturalized to the normal morphology (tenses) of the target language[12]. For example:

\section{SL: Amputation \\ TL: Amputasi}




\section{c. Cultural Equivalent}

Cultural equivalent: it means replacing a cultural word in the SL with a TL one. However, "they are not accurate"[12]. Cultural equivalent: Substitution of cultural words from the source language into the target language. Although, "the word is not accurate". For example:

\section{Pajamas party (SL): menginap bersama (TL)}

\section{d. Functional Equivalent}

Newmark[12] revealed that functional equivalent requires the use of the word culture-neutral. The researcher assumes that this type of translation procedure requires the translator to find an equivalent word in the target language that expresses a similar concept, for example:

Driving license (ST): surat iæin mengemudi (TL)

\section{e. Descriptive Equivalent}

Newmark states the description takes into account the function. Descriptive equivalent includes translating the source language using the description according to the concept intended in the target language. For example:

(1) machete: the description is 'a broad, heavy Latin American instrument', its function is 'cutting or aggression'; the description and function are combined in the 'knife'.

(2) Bajaj: a traditional three-wheeled vehicle which is usually located in Jakarta.

Description and function are important elements in the explanation and hence in translation. In translation discussions, functions were ignored; now tends to be overplayed.

\section{f. Synonymy}

Synonymy is almost equivalent to TL[12]. The researcher assumes that this type of translation procedure is to find other meanings in the word TL to be as likely as the word SL. Synonymy translates SL words with target language expressions that are almost, but not completely, functionally equivalent, for example:

$$
\begin{aligned}
& \text { SL: amazed } \\
& \text { TL: takjub/kagum }
\end{aligned}
$$

\section{g. Through-translation}

A direct translation or through translation is a literal translation of a general collocation, the name of the organization and components of compounds that have been recognized. This can also be called a translation of a loan or loan[12]. For example: UNESCO is translated directly and does not change the word in TL. This happens because UNESCO (United Nations Educational Scientific and Organization) is the name of the UN organization that deals with education and science.

\section{h. Shift or Transposition.}

Shift or transposition: this involves changes in grammar from SL to TL, for example, (i) changes from singular to plural, (ii) changes needed when certain SL structures are not present in TL, (iii) changes from SL verbs to words TL, SL noun group changes to TL nouns and so on[12].

According to the previous description, the researcher draws the conclusion that shift or transposition is a procedure that changes grammar without losing its meaning. Examples of grammar changes are changes from singular to plural, groups of nouns to nouns, verbs to nouns and much more. For example:

\section{SL: damn beautiful \\ TL: cantik sekali}

\section{i. Modulation}

Modulation occurs when the translator reproduces the original text message in the TL text according to the current TL norms, because SL and TL might look different in terms of Newmark's perspective[12]. In other words, modulation means a change in perspective or conceptual concept that is substantial in translation, for example, using category names for members of certain categories, using parts for the whole (and vice versa), active for passive etc. The researcher concludes that this type of translation procedure allows translators to bring their own concepts based on TL culture to change the point of view when translated but still convey the same ideas as the SL word, for example:

\section{SL: Dia selalu terlambat}

TL: he is never on time/he's never be on time. 


\section{Hasibuan, H.N.H.D. \& Musfiroh, T. The Analysis of Swearing Word Translation in Joker Movie Subtitle}

\section{j. Recognized Translation}

This happens when translators usually use official translations or whatever institutional terms are generally accepted by Newmark[12]. It can also mean to use a well-known translation of the target language for the term institutional in the source language. According to the previous description, the researcher believes that this type of translation procedure usually occurs when the translator uses the general translation that exists in TL culture for SL institutional terms, for example

\section{SL: Interpol Headquarter}

TL: kantor polisi pusat

\section{k. Label Translation}

This translation is a temporary translation of the target language from the source language terms that do not have conventional translations in the target language. This translation can also use literal translation, example:

ST: Heritage language

TT: Erbscharts Sprache, langue d'heritage

\section{Compensation}

Compensation occurs when the reduction of meaning in one part of a sentence and compensated in another part of Newmark[12]. Compensation occurs when the SL word cannot be translated and the missing meaning is stated in another part of the text. Compensation means making up for losing something in the source text, by adding something else in the target text.

Example: A piece of ... (ST): Sedikit ...

\section{m. Componential analysis}

Comparison between SL words and TL words that have similar meanings, but it is not one-to-one equivalent, by first showing them together and then their different sensory components can be called componential analysis[12]. Componential analysis means comparing words in the source language with words in the target language that have almost the same word but not in the same detail, by demonstrating the first component in general then the difference. Example:

Clean air $(\mathrm{SL})=$ Udara Segar $(\mathrm{TL})$.
Sweet talk (SL) = Kata-kata manis (TL).

\section{n. Paraphrase}

This procedure of translation is far more detailed than Newmark's descriptive equivalent[12]. According to previous explanations, researchers assume that paraphrase is a restatement using other words from the original text. For example:

Ablutophobia, or fear of bathing, is a relative uncommon but serious phobia. It appears to be more prevalent in women and children. (takut untuk mandi adalah hal yang relatif tidak biasa namun merupakan phobia yang serius. Hal ini muncul secara lebih lazim pada wanita dan anak-anak).

\section{o. Couplets}

This translation occurs when the translator combines two different procedures Newmark (1988: 91). In other words, the translator might use two or more translation procedures to translate into TL words.

Example: (SL) menu: (TL) menu (transference and naturalization)

\section{p. Notes, Additions, Glosses}

Newmark revealed that the notes were additional information[12]. According to the explanation, the researcher assumed that the notes were additional information that the translator wanted to add to the translation. The various forms for notes are (1) in text; (2) as footnotes; (3) as a final note; and (4) notes or glossary at the end of the book for example: Karimunjawa (island in the Java Sea, located near Jepara, Central Java).

\section{Swearing Words}

Andersson and Trudgill[2] define swearing as: refers to something that is taboo and/or stigmatized in the culture, should not be interpreted literally and can be used to express strong emotions and attitudes. Hill[6] argues that swearing words are a way of speaking that some people use to express feelings of anger, annoyance, and frustration or when they want to hurt the feelings of others. The same idea was put forward by Adam \& Richard[1]. They state that swearing words are unacceptable and harsh language words; they are among the strongest and most offensive words. Usually swearing words are words 
that show disrespect, defamation or humiliation of someone or something, or just the act of expressing intense movements.

In addition, Ljung[8] stated that swearing is an emotive language, where the main function is to express the feelings of the speaker. The act of swearing to release emotion does not only apply to the experience of negative feelings such as anger, fear, pain, or even frustration, sadness, etc. Swearwords can also be used in conjunction with decidedly positive emotional experiences, such as happiness, surprise, intimacy, or humor[4].

Swearing words present many different functions in different social contexts Holmes in Nordquist[13]. In general swearing words are very rude, abusive, or offensive and are also related to insults to others, or related to strong feelings toward something. Humans may express resentment, aggression and humiliation, or they can express solidarity and friendliness. So, swearing word is the word that has function to express the human feelings, does not only the negative but also the positive expression.

According to Michael Swan[15], swear words are strong language that expressed by person to their powerful emotion. Generally, this expression comes from taboo word that literally same. Swear word has two types of categories: strong swear words and weak swear words.

\section{a. Strong Swear Word}

Strong swear words have bad or rude meaning to listen and the usage of strong swear word is expressed by people to their powerful emotion. Types: of strong swear word:

\begin{tabular}{llrl}
\hline No. & \multicolumn{1}{c}{ Type } & \multicolumn{1}{c}{ Expression } \\
\hline $\mathbf{1}$ & $\begin{array}{l}\text { Exclamation } \\
\text { Annoyance } \\
\text { Exclamation } \\
\text { surprise }\end{array}$ & of & $\begin{array}{l}\text { Fuck! God Damn! shit! damn } \\
\text { it! God damn! bastard! } \\
\text { Fuck me! shit me! damn me! } \\
\text { suck me! }\end{array}$ \\
$\mathbf{3}$ & $\begin{array}{l}\text { Exclamation } \\
\text { unconcen } \\
\text { Insult }\end{array}$ & of & I don't give a damn/shit/fuck \\
& & & $\begin{array}{l}\text { Asshole, bastard, damn, cunt, } \\
\text { fuck, bitch, son of a bitch, } \\
\text { Dickhead, suck, shit, fucker, } \\
\text { mother fucker, fart, } \\
\text { cocksucker, prick }\end{array}$ \\
& & Fuck off! Piss off! Screw!
\end{tabular}

6 emphasize an emotion

$7 \quad$ Surprised question

8

Violent refusal/rejection
Damn(ed), fuck, goddamn

Who/what/where/why/how the hell...?"

Fucked if I will! Stuff it up your ass! Shut the fuck up! Suck this!

Table 1. Strong Swear Words

\section{b. Weak swear word}

Weak swear word is not as harsh as expressions of the first swear word. Types of weak swear word:

\begin{tabular}{|c|c|c|}
\hline No & Type & Expression \\
\hline 1 & Exclamation of Annoyance & $\begin{array}{l}\text { Oh jess! gosh! blah! } \\
\text { ouch! }\end{array}$ \\
\hline 2 & Exclamation of Surprise & $\begin{array}{l}\text { Oh my God! fool me! } \\
\text { Jesus crist! }\end{array}$ \\
\hline 3 & Emphasize and Emotion & $\begin{array}{l}\text { Oh dear! My } \\
\text { goodness! Dear God! }\end{array}$ \\
\hline 4 & Insult & $\begin{array}{l}\text { Dummy! Fool! Idiot! } \\
\text { coward! stupid! }\end{array}$ \\
\hline
\end{tabular}

Table 2. Weak Swear Words

Stapleton (2010) describes four interpersonal functions of 'swearing': expressing emotion; constructing/displaying identity; social bonding and solidarity; humor and verbal emphasis. More generally, five functions are commonly mentioned in the literature:

1. Expression of emotion (e.g. anger, surprise, excitement) or pain (sometimes called "expletive" function): Oh shit I'm getting lost

2. Abusive/insulting (derogatory, functions to insult): the people on night fills are arseholes

3. Social distance/solidarity (group membership): ... I'll never forget them little shits dressed me up as a fucking angel [laughs]

4. Emphasis/intensification: she was bloody silly; a fucking big problem; beat the hell out of each other

5. Stylistic/idiomatic/humorous/idiosyncratic: ...So the little Irish bloody pilot gets up $n$ he says 'I'm five foot two n I'm sitting up the bloody front'. 


\section{Hasibuan, H.N.H.D. \& Musfiroh, T. The Analysis of Swearing Word Translation in Joker Movie Subtitle}

\section{METHODOLOGY}

This research used descriptive qualitative method. Qualitative research is research that intends to understand the phenomena about what is experienced by research subjects holistically, and by means of descriptions in the form of words and language, in a special natural context and by utilizing various scientific methods[9]. The type of research approach is descriptive. Descriptive research is research that seeks to tell the solution of existing problems based on data. This type of descriptive qualitative research used in this study is intended to analyze the type and translation procedures in the swearing word in the film.

The object of research can be stated as a social situation of research that wants to know what is happening in it. In the object of this study, researchers can observe in depth the activities (activities) of people (actors) that exist in certain places. The object of this research is the Joker movie subtitle transcript. Subtitles related to swearing words. The data source is taken from www.subscene.com.

The subject of this research is the form of words, phrases, clauses and even sentences taken from the dialogue in the joker. To get the right data, an informant who has competency and in accordance with the data needs (purposive) needs to be determined. This study aims to find swearing words in English to Indonesian subtitles from the Joker movie and to describe the types of translation procedures used by translators to translate swearing words in Joker movies.

The key instrument of this research is human instrument. The researcher is the person who wants to find the research problems. In qualitative research, according to Moleong[9] the researcher acts as the main instrument.

These are the steps of data collection. First, researchers download movies and search for joker movie subtitles in both English and Indonesian. Second, researchers watch movies and read English and Indonesian movie subtitles. Next, the researchers made a list of swearing words found in translations from the English subtitles of the Joker movie.
The analysis is carried out through several steps. First, researchers made a list of English and Indonesian translations of the swearing words found in the Joker movie subtitles. Second, researcher classify those words based on Swam's type of swearing word theory. After that, researchers analyze data one by one from the theory about the types of translation procedures proposed by Newmark. The final procedure, the researcher gives a brief explanation of each type of translation procedure used by the translator in translating the swearing word and gives 2 data each procedure.

\section{RESULT AND DISCUSSION}

\section{Result}

According to Michael Swan[15], swear words are strong language that expressed by person to their powerful emotion. Swear word has two types, there are strong and weak swear word. This research found 49 swearing words in the Joker movie. Here, the finding table of the type of swearing word and the procedure used in the Joker Movie Subtitle.

\begin{tabular}{|c|c|c|c|c|}
\hline No. & & Type & Amount & $(\%)$ \\
\hline \multirow[t]{6}{*}{1} & $\begin{array}{l}\text { Strong } \\
\text { swear }\end{array}$ & $\begin{array}{l}\text { Exclamation of } \\
\text { Annoyance }\end{array}$ & 11 & $22.4 \%$ \\
\hline & word & $\begin{array}{l}\text { Exclamation of } \\
\text { surprise }\end{array}$ & 6 & $12.2 \%$ \\
\hline & & $\begin{array}{l}\text { Exclamation of } \\
\text { unconcern }\end{array}$ & 2 & $4.1 \%$ \\
\hline & & Insult & 3 & $6.1 \%$ \\
\hline & & $\begin{array}{l}\text { Emphasize an } \\
\text { emotion }\end{array}$ & 15 & $30.6 \%$ \\
\hline & & $\begin{array}{l}\text { Surprised } \\
\text { question }\end{array}$ & 4 & $8.2 \%$ \\
\hline \multirow[t]{3}{*}{2} & $\begin{array}{l}\text { Weak } \\
\text { swear }\end{array}$ & $\begin{array}{l}\text { Exclamation of } \\
\text { Surprise }\end{array}$ & 2 & $4.1 \%$ \\
\hline & word & $\begin{array}{l}\text { Emphasize and } \\
\text { Emotion }\end{array}$ & 2 & $4.1 \%$ \\
\hline & & Insult & 4 & $8.2 \%$ \\
\hline \multicolumn{2}{|c|}{ TOTAL } & & 49 & $100 \%$ \\
\hline
\end{tabular}

The table above refers to the types of the swearing words. The swearing words are divided into two types: the strong swear word and the weak swear word. The most frequently type is a emphasize an emotion of strong swear word type. This is because swearing words are usually used express human emotions. In line with Ljung[8] stated that swearing is an emotive language, where the main function is to express the feelings of the speaker. 
The next table is the procedure translation of swearing word table. The procedure translation that used in translating swearing words is only 5 of 15 procedures, based on Newmark[12].

\begin{tabular}{|c|c|c|c|}
\hline No. & Procedures & Amount & Percentage \\
\hline 1 & $\begin{array}{l}\text { Cultural } \\
\text { Equivalent }\end{array}$ & 24 & $49 \%$ \\
\hline 2 & Synonymy & 6 & $12 \%$ \\
\hline 3 & $\begin{array}{l}\text { through- } \\
\text { translation }\end{array}$ & 6 & $12 \%$ \\
\hline 4 & $\begin{array}{l}\text { Shift(transpositio } \\
\text { n) }\end{array}$ & 10 & $20 \%$ \\
\hline 5 & Paraphrase & 3 & $6 \%$ \\
\hline Total & & 49 & $100 \%$ \\
\hline
\end{tabular}

Tabel 4. Frequency of the procedure translation

From the procedure translation table, it can be concluded that the cultural equivalent is most often found in translating the swearing words. According to Newmark[12] cultural equivalent it means replacing a cultural word in the SL with a TL one. So, cultural equivalent procedure used for making the watcher/reader in TL easier to understand the movie subtitle.

\section{Discussion}

The act of swearing to release emotion does not only apply to the experience of negative feelings such as anger, fear, pain, or even frustration, sadness, etc. Swearwords can also be used in conjunction with decidedly positive emotional experiences, such as happiness, surprise, intimacy, or humour[4]. In Bahasa Indonesia as target text, Wijana and Rohmadi[17] explain that the forms of invective are the language tools needed by speakers to express displeasure and react to various phenomena that cause such feelings. In addition, they state that the swearing system in Indonesian can be classified into various types, namely (1) conditions, (2) animals, (3) objects, (4) parts of the body, (5) kinship, (6) spirits, (7) activities, (8) professions, and (9) exclamations. From the explanation, it concluded that swearing word is used to express human emotion, bad or good emotion.

The research discussed the swearing words from Joker movie and their translation in Bahasa Indonesia. After conducted the research, the Joker movies has 2 types of swearing word: strong and weak swear word types. for the strong swear word divided into exclamation of annoyance, exclamation of surprise, exclamation of unconcern, insult, emphasize an emotion, surprised question. The weak swear words are exclamation of surprise, emphasize an emotion, insult.

The research also revealed that of the 15 types of translation procedures proposed by Newmark[12] only 5 types of translation procedures were used by translators in translating swearing words. Here, the analysis procedure translation and type of swearing word.

\section{a. Cultural Equivalent}

The research revealed 24 swearing words that used cultural equivalent in translation. The swearing word translation above is in line with the theory of the type of translation procedure proposed by Newmark[12]. Newmark revealed that cultural equivalent replaced the word culture in SL with TL. The researcher can conclude based on the theory that this type of translation procedure allows translators to shift words with equivalent TL cultural words even though their equivalents are very different but still convey similar meanings.

Here are some samples from the research data above:

Data (1)

\begin{tabular}{clc}
\hline Times & \multicolumn{1}{c}{ Sentences } & Type \\
\hline 01.49.51 & $\begin{array}{l}\text { SL: You get what you fucking } \\
\text { deserve }\end{array}$ & $\begin{array}{c}\text { Strong } \\
\text { (Emphasize }\end{array}$ \\
& $\begin{array}{l}\text { TL: Kau dapat yang layak kau } \\
\text { terima }\end{array}$ & an emotion) \\
Context & Joker swore the sentence to the \\
& Murai TV host), he felt that \\
& $\begin{array}{l}\text { Murai ask him to join the show } \\
\text { only for making him fun in front } \\
\text { of the audience. }\end{array}$ \\
\hline
\end{tabular}

The data above shows that Joker swore to emphasize his anger emotion, based on Stapleton's interpersonal function of swearing[14]. The word fucking deserve is translated into the equivalent word in TL. The researcher believes that the translator uses the proper word to translate the SL word. Since the words are equivalent in the context of the language and are equivalent to the culture of words in Indonesia. Therefore, the data are consistent with the theory of procedure translation proposed by Newmark[12]. 
Data (2)

\begin{tabular}{|c|c|c|}
\hline Times & Sentences & Type \\
\hline $00: 08: 20$ & $\begin{array}{l}\text { SL: They don't give a shit of } \\
\text { people like you } \\
\text { TL: Mereka tidak peduli kepada } \\
\text { orang sepertimu Arthur }\end{array}$ & $\begin{array}{c}\text { Strong } \\
\text { (Emphasize } \\
\text { an emotion) }\end{array}$ \\
\hline Context & $\begin{array}{l}\text { Arthur's psychiatrist expressed } \\
\text { the swearing word to emphasize } \\
\text { her emotion while talking to him. } \\
\text { So that Arthur understood that } \\
\text { there is no one care about him } \\
\text { now. }\end{array}$ & \\
\hline
\end{tabular}

The researcher assumes that translator used the word 'peduli' (caring) because they have to adjust to the suitability of the culture in the target language, Indonesian. In other words, 'peduli' is more accepted in Indonesian. As the author mentioned before, this type of translation procedure is like shifting words with TL that is equivalent to the word culture.

\section{b. Synonymy}

Researchers found that there were 6 translations of sworn words belonging to synonyms. The swearing word translation is in accordance with the theory of the types of translation procedures by Newmark[12]. Newmark proposes that a synonym is a word that is equivalent to TL. In other words, this type of translation procedure finds the closest meaning.

\begin{tabular}{cll}
$\begin{array}{c}\text { Data (3) } \\
\text { Times }\end{array}$ & \multicolumn{1}{c}{ Sentences } & Types \\
\hline 00:18:20 & $\begin{array}{l}\text { SL: They think you're weird } \\
\text { TL: Mereka pikir kau aneh }\end{array}$ & $\begin{array}{l}\text { Weak } \\
\text { Context } \\
\text { (Conversation between boss and } \\
\\
\text { Arthur), The boss swore him because } \\
\text { the world thought Arthur is the weird. }\end{array}$ \\
& & \\
\hline
\end{tabular}

The word 'weird' is translated into 'aneh'. It means that the translator used synonyms in translating swearing word due to the TL has the equivalent word[12]. Researchers assume that translators must find the TL word that is the closest and most suitable for expressing swearing words.

Data (4)

\begin{tabular}{cll}
\hline Times & \multicolumn{1}{c}{ Sentences } & \multicolumn{1}{c}{ Types } \\
\hline 00:18:22 & $\begin{array}{l}\text { SL: Bullshit } \\
\text { TL: Omong kosong }\end{array}$ & $\begin{array}{l}\text { Strong } \\
\text { (Exclamation of } \\
\text { annoyance) }\end{array}$ \\
Context & $\begin{array}{l}\text { The boss felt Arthur's } \\
\text { answer does not make } \\
\text { sense }\end{array}$ & \\
\hline
\end{tabular}

The following data is similar to the previous one. Data used synonymous procedure because the translation is used near words equivalent to TL[12]. Here, researchers find that the synonym of the translated swearing word 'bulshit' is 'omong kosong'. That means the words SL and TL are close because they both are still dealing with something that is not of sufficient quality.

\section{c. Through-translation}

The data above shows that there are 6 swearing word translations in through-translation. Swearing word translations are found in line with theories about through translation by Newmark[12]. Newmark proposes that through translation is a type of translation procedure that has literal translations such as collocation, organization, compound components and combinations.

\begin{tabular}{clc} 
Data (5) & & \\
\hline Times & \multicolumn{1}{c}{ Sentences } & \multicolumn{1}{c}{ Types } \\
\hline $\mathbf{0 0 . 3 0 . 4 9}$ & $\begin{array}{l}\text { SL: Something funny, } \\
\text { asshole? } \\
\text { TL: Ada yang lucu, keparat? }\end{array}$ & $\begin{array}{c}\text { Strong } \\
\text { (Exclamation } \\
\text { of annoyance) }\end{array}$ \\
Context & $\begin{array}{l}\text { While Arthur laughed in the } \\
\text { train and the three boys felt } \\
\text { the annoyance of his laughing. } \\
\\
\begin{array}{l}\text { One of them asked him } \\
\text { through strong emotion }\end{array}\end{array}$ \\
\hline
\end{tabular}

The data shows that swearing consists of two words that always occur together. If the words appear themselves then the meaning has changed, for the word asshole can be divided into ass and hole which have different meanings if standing together. In other words, swearing words can belong to the translation because words consist of two words combined into one phrase.

Data (6)

\begin{tabular}{clc}
\hline Times & \multicolumn{1}{c}{ Sentences } & Type \\
\hline $\mathbf{0 0 . 1 5 . 5 9}$ & SL: Fucking savages & $\begin{array}{c}\text { Strong } \\
\text { (Insult) }\end{array}$ \\
& $\begin{array}{l}\text { TL: Bajingan } \\
\text { Context }\end{array}$ & $\begin{array}{l}\text { Arthur's friend insulted the kids that } \\
\text { have bullied Arthur. }\end{array}$ \\
\hline
\end{tabular}

The following data is also similar to the previous one which swearing words consisting of two words then combined into one word can be classified in the Newmark translation procedure[12]. The author 
believes that the word swear has a different meaning if they stand together like the previous data. If the words are combined into one phrase, they can have different meanings, which are frightening.

\section{d. Shifts or Transpositions}

This study revealed that there were 10 swearing word translations that included shifts or transpositions. The translation of the swearing words found is in accordance with Newmark's theory about the types of translation procedures. Newmark revealed that shift or transposition involves changing the grammatical form of the word SL into the word TL.

Data (7)

\begin{tabular}{clc}
\hline Times & \multicolumn{1}{c}{ Sentences } & Type \\
\hline $\mathbf{0 1 . 2 9 . 1 4}$ & SL: Fuck & $\begin{array}{c}\text { Weak } \\
\text { (Exclamation of } \\
\text { annoyance) }\end{array}$ \\
TL: Sial & & \\
Context & $\begin{array}{l}\text { Gary (Arthur's friend) is } \\
\text { afraid because Arthur } \\
\text { has killed their friend in } \\
\text { front of him. }\end{array}$ & \\
\hline
\end{tabular}

The data shows the same grammatical structure changes as the previous data. The grammatical structure of the swearing word translation shifts from nouns to adjectives. The data comes from the fuck sentence, researchers see that this is translated in 'sial'. It is clear that the data is in line with the theory of the type of translation or transposition procedure proposed by Newmark[12].

Data (8)

\begin{tabular}{clc}
\hline Times & \multicolumn{1}{c}{ Sentences } & Type \\
\hline $\mathbf{0 0 . 2 9 . 0 8}$ & SL: you're fuck up and & $\begin{array}{c}\text { Strong } \\
\text { (Emphasize an } \\
\text { emotion) }\end{array}$ \\
& TLu're liar Kau pengecut dan & \\
& kamu pembohong & \\
Context & While calling the boss, & \\
& Arthur got the swearing & \\
& word from his boss. & \\
& Because the boss felt \\
& disappointed of his job. & \\
\hline
\end{tabular}

The data revealed that the swearing word translation was translated through a shift or transposition procedure because the grammatical structure of the SL word was transformed into TL Newmark[12]. The grammar structure of 'fuck up' in a swearing word translation is transferred from verbs to adjectives. The data comes from fuck up sentences which translate into 'pengecut'. The researcher believes that there is a grammatical structure that changes from swear words and translations. The author's idea is in line with Jensen's[7] idea that shift or transposition is about the translation of SL words into TL words that involve changes in grammatical structure.

\section{e. Paraphrase}

The researcher assumes that paraphrase is a restatement using other words from the original text. Researchers found 3 translation data that belonged to the paraphrase procedure category.

\begin{tabular}{clc} 
Data (9) & \multicolumn{1}{c}{ Sentences } & Type \\
\hline Times & \multicolumn{1}{c}{$\begin{array}{c}\text { Strong } \\
\text { 00.16.37 }\end{array}$} & $\begin{array}{l}\text { SL: You got a fuck too } \\
\text { TL: kan akan celaka } \\
\text { Contextamation of } \\
\text { annoyance) }\end{array}$ \\
& $\begin{array}{l}\text { Randall (Arthur's friend) } \\
\text { gave Arthur a gun, it is for } \\
\text { keeping Arthur safe. }\end{array}$ & \\
\hline
\end{tabular}

The data above shows that the sentence 'you got a fuck too', it is clear that the speaker swore his opponent to feel the same. This swearing word type is exclamation of annoyance. The swearing word produced because the speaker felt annoyance of his conversation partner.

Data (10)

\begin{tabular}{|c|c|c|}
\hline Times & Sentences & Type \\
\hline 00.37 .32 & $\begin{array}{l}\text { SL: Stop talking out of } \\
\text { your ass, Art. } \\
\text { TL:Berhenti mengada- } \\
\text { ngada }\end{array}$ & $\begin{array}{c}\text { Strong } \\
\text { (Emphasize an } \\
\text { emotion) }\end{array}$ \\
\hline Context & $\begin{array}{l}\text { Randal was swearing. He } \\
\text { is asked by Arthur to tell } \\
\text { why he was fire from the } \\
\text { office. Randall act like he } \\
\text { didn't know anything. }\end{array}$ & \\
\hline
\end{tabular}

Data (10), this swearing word use paraphrase procedure in translating the word. According to Newmark's paraphrase is re-statement the ST to TL. Researcher assumed that the translator uses paraphrase in explaining meaning directly.

Translation procedures used in translating the swearing word from Joker movie is acceptable and has the high readability level. This is due to the translation feels natural; technical terms used commonly used and familiar to readers; phrases, 


\section{Hasibuan, H.N.H.D. \& Musfiroh, T. The Analysis of Swearing Word Translation in Joker Movie Subtitle}

clauses and sentences. Furthermore, the translation made the watcher/ reader easier to understand the movie[10].

\section{CONCLUSION}

After conducting research, it can be concluded that the research collects 49 swearing words in the Joker movie. The research found two types of swearing words according to Swan[15], it shows that 6 of 8 types from strong swear word type and 4 weak swear word types. The emphasize an emotion is the most frequently type in the movie. The researchers agreed that different culture between SL and TL that can affect the swearing word translation. The result showed that only 5 of 15 procedures used by translators to translate the swearing words of the Joker movie include: cultural equivalent, synonymy, through-translation, shit or transposition, and paraphrase. The translation procedure that is often used by translators is cultural equivalent, the results of the study reached 24 of 49 data.

\section{REFERENCES}

[1] Adam K. \& Richard, F. (2002). Glossary. Using English. Retrieved December, 2019.

[2] Andersson, L. \& Trudgill, P. (1990). Bad language. Oxford: Blackwell.

[3] Dewi. B.I.K (2019). Swear words translation of Indonesian subtitle of Spy movie. Yogyakarta : Universitas Sanata Dharma

[4] Fägersten, K. B. \& Stapleton, K. (2017). Swearing research as variations on a theme. John Benjamins Publishing Company

[5] Harvey, P. (2011). Why we swear. Eureka Street, p. 41-42.

[6] Hill, J. (2004). Swearing - Using Bad Words. South Australia: Women's and Children's Health, Network.

[7] Jensen, E.K. (2008). Translation and Translation Theory. University of Aalborg.

[8] Ljung, M. 2011. Swearing: A Cross-Cultural Linguistic Study. London: Palgrave Macmillan
[9] Moleong, L. J. (2001). Metode penelitian kualitatif. Bandung: PT Penerbit Remaja Rosdakarya.

[10] Nababan, M. (2012). Pengembangan model penilaian kualitas terjemahan. Kajian Linguistik dan Sastra, 24(1), 39-57. https://publikasiilmiah.ums.ac.id/handle/1161 $\underline{7 / 2220}$

[11] Newmark, P (1981). Approaches to translation, Oxford: Pergamon Press.

[12] Newmark, P. (1988). A textbook of translation. London: Prentice Hall International.Ebook.

[13] Nordquist, R. (2018). What are swear words and what are they used for?. ThoughtCo, retrieved at Dec. 7, 2018, from https://www.thoughtco.com/swear-word$\underline{\text { term-1691888 }}$

[14] Stapleton, K. 2010. Swearing. In Interpersonal Pragmatics, ed. by Miriam A. Locher \& Sage L. Graham, 289-306. Vol. 6 of Handbooks of Pragmatics, ed. by Wolfram Bublitz, Andreas H. Jucker \& Klaus P. Schneider. Berlin: Mouton de Gruyter

[15] Swan, M. (1995). Practical English usage. Oxford: Oxford University Press.

[16] Vitasari, I. (2013) Analysis on the translation of swear words produced by two main characters in A Very Harold and Kumar Christmas Movie. LANTERN, Vol 2(2), p. 69-76

http:/ /103.28.220.26/?ref=browse\&mod=view article \&article $=73996$

[17] Wijana, I. D. P. dan Rohmadi, M. 2006. Sosiolinguistik: Kajian teori dan analisis. Yogyakarta: Pustaka Pelajar. 